\title{
CHEMICAL COMPOSITION OF LAGOON MUDS
}

\author{
By V. Krishna Pillai \\ (Central Marine Fisheries Research Station, Mandapam Camp) \\ Received June 5, 1956 \\ (Communicated by Dr. N. K. Panikkar, F.A.sc.)
}

\section{INTRODUCTION}

IT has been shown in earlier communications (Krishna Pillai, 1954, -1955) that the conditions existing in salt-water lagoons bear no similarity to those found either in open sea or in fresh-waters and that productivity in the lagoons is controlled by factors that differ in nature and degree of influence from those of the natural environments. The changes taking place in the water and surface algæ from saline lagoons have also been discussed in the above communications. But in order to have a full appraisal of the production potential of these areas it becomes necessary to study the composition of the bottom muds. The fundamental work of Mortimer $(1941,1942)$ suggested that the physical and chemical characteristics of bottom deposits might play a significant part in the productivity of estuarine and other similar regions. Considering the fact that the lagoons remain isolated from the sea for long periods the role of bottom deposits as sources of nutrients become all the more significant.

Normally the Palk Bay Lagoons are subjected to four different types of ecological conditions every year. They are:-

1. A period of dry season between May and October. The mud is subjected to extreme heat and is converted into a hard mass.

2. Inundation of the area with rain-water during October-November. The rain-water dissolves the salts from the mud and the salinity rises to about $2 \%$. Growth of algæ and other planktonic organisms does not seem to commence immediately after inundation; but later organisms characteristic of brackish-water environment begin to grow.

3. Opening of the Bar towards the end of the rainy season, generally about the end of October or the beginning of November, and entry of sea-water into the lagoons. Due to constant admixture with sea-water a true marine environment is created and growth of planktonic organisms continue at a normal rate. 
4. Closing of the connections between the sea and the lagoons in MarchApril. The salinity of the water increases thenceforth at a rapid rate and a stage is reached when the salt crystallises and forms a layer above the bottom mud.

Under these extreme conditions the bottom deposits also undergo drastic changes. In the present communication data relating to some of the major changes taking place in the bottom muds of the Palk Bay Lagoons are given.

\section{EXPERIMENTAL}

The periodic collections of bottom deposits were made from the same stations as for the previous investigations. For the study of the surface muds the first six inches layer was collected using an ordinary soil sampler. Two sets of collections were made from three different layers (the surface $4^{\prime \prime}$ layer, the middle 4 " layer and the bottom $4^{\prime \prime}$ layer) from both the stations with a view to study the variations in the chemical composition between the different layers of the mud. Even in natural environment in the Clyde Sea area Moore (1930) was able to notice a decrease in the P and $\mathrm{N}$ contents of the muds with depth. The soil sampler which is sharpened at the free end is forced down vertically into the mud to a depth of one foot. After it is taken out the sample is pushed out with the aid of the piston in the form of a cylinder. This is then divided into different layers for analyses.

The samples were analysed for their $\mathrm{pH}$, silt, loss on ignition, total nitrogen, total and interstitial phosphorus and the water-soluble constituents such as calcium, iron, chloride, sulphate and nitrate. The methods employed for the analyses are those recommended by the A.O.A.C. (1950, pp. 29-46) and by Rochford (1951).

Altogether six sets of collections were made during the period from October 1953 to July 1954 . The results of analysis of the samples collected are presented in Table I. Only the first two and the last sets were analysed for their silt and phosphorus contents and the results are tabulated in Table II.

\section{DisCUSSION OF RESULTS}

From the values given in the table it may be seen that the lagoon muds are more alkaline when they remain in the dry state. This may indicate that decomposition of organic matter is very much limited during the period of drought.

The organic matter content, as indicated roughly by the loss on ignition of the samples, shows a definite change. During October, immediately before the rains when the bottom looks like a hardened mass, the organic matter 
TABLE I

Analysis of Soil Samples Collected from Palk Bay Lagoons during Different Months

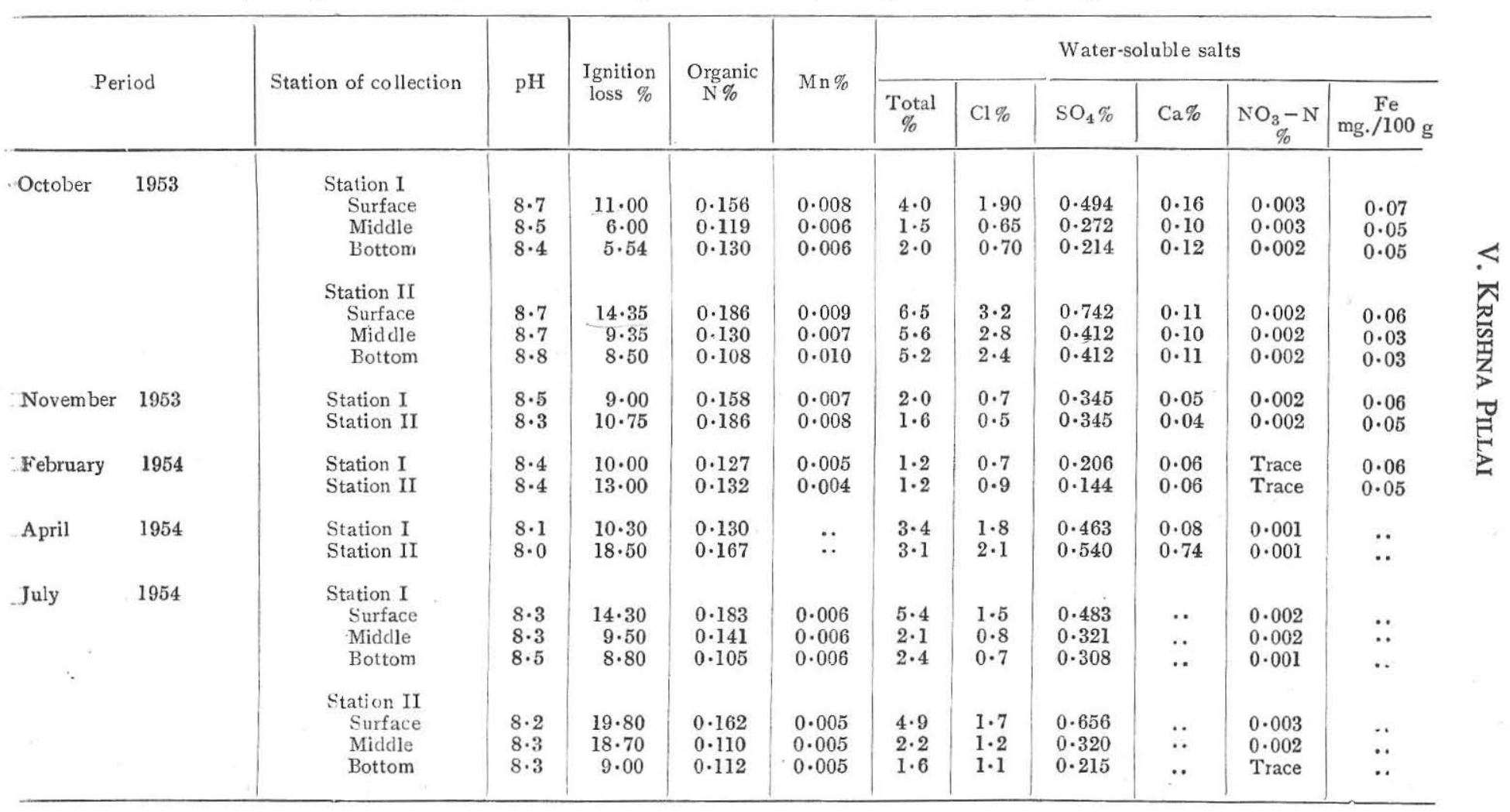


TABLE II

Silt and Phosphorus Contents in Mud Samples Collected from Palk Bay Lagoons

\begin{tabular}{lcccc}
\hline $\begin{array}{l}\text { Period of } \\
\text { collection }\end{array}$ & $\begin{array}{c}\text { Place of } \\
\text { collection }\end{array}$ & $\begin{array}{c}\text { Silt } \\
\%\end{array}$ & $\begin{array}{c}\text { Total phosphorus } \\
\mu \mathrm{g} . / \mathrm{g} . \text { of silt }\end{array}$ & $\begin{array}{c}\text { Interstitial } \\
\text { phosphorus } \\
\mu \mathrm{g} . / \mathrm{g} . \text { of mud }\end{array}$ \\
\hline
\end{tabular}

October 1953 Station I

$\begin{array}{lrrc}\text { Surface } & 22 \cdot 1 & 307 \cdot 7 & \ldots \\ \text { Middle } & 18 \cdot 0 & 235 \cdot 0 & \ldots \\ \text { Bottom } & 4 \cdot 3 & 463 \cdot 9 & 5 \cdot 82\end{array}$

Station II

$\begin{array}{llll}\text { Surface } & 19 \cdot 2 & 448 \cdot 7 & 5 \cdot 09 \\ \text { Middle } & 17 \cdot 4 & 319 \cdot 9 & 4 \cdot 67 \\ \text { Bottom } & 12 \cdot 0 & 290 \cdot 0 & 4 \cdot 57\end{array}$

November

Station I

$13 \cdot 0$

$453 \cdot 8$

$5 \cdot 06$

1953

Station II

$13 \cdot 0$

$477 \cdot 0$

$6 \cdot 37$

July 1954 Station I

$\begin{array}{llll}\text { Surface } & 16 \cdot 3 & 343 \cdot 5 & 6 \cdot 30 \\ \text { Middle } & 12 \cdot 3 & 260 \cdot 2 & 5 \cdot 00 \\ \text { Bottom } & 10 \cdot 8 & 202 \cdot 0 & 4 \cdot 70\end{array}$

Station II

Surface

$17 \cdot 9$

$632 \cdot 4$

$5 \cdot 80$

Middle

$14 \cdot 3$

$372 \cdot 0$

$4 \cdot 40$

Bottom

$9 \cdot 5$

$322 \cdot 1$

$4 \cdot 20$

content at both stations remains somewhat high, the loss on ignition being $11.0 \%$ at Station I and 14.35 at Station II. When once the area gets inundated with rain-water a part of the silt and colloidal organic matter and most of the soluble salts are taken up by the water and made available for the growth of various organisms. This is followed by a slight decrease in the organic matter content of the mud. For example in November collections the loss on ignition of the sample from Station I is $9.0 \%$ while that for Station II is $10.75 \%$. During the next stage when the lagoon is connected with the sea 
all natural conditions are created for the normal growth of organisms. But when once the connections are closed the salinity of the water increases and plant life ceases gradually. During these changes all the dying organisms are collected along with the bottom deposits adding considerably to the organic matter content of the mud samples. In April 1954 just before the connections are closed the loss on ignition of the mud samples from Station I increases to $10 \cdot 3 \%$ and that at Station II to $18 \cdot 5 \%$. The surface samples collected during July 1954 show a still further increase in the organic matter content, the loss on ignition of samples being $14 \cdot 3 \%$ and $19 \cdot 8 \%$ respectively for Stations I and II.

The bottom deposits remain exposed to the sun during May to October: During this period the moisture content of the soil decreases rapidly reaching a minimum during September to October. But in the beginning of this dry season the soil contains enough moisture to promote bacterial decomposition of the organic matter. Thus a lowering of the organic matter content is observed in the October collections from both the stations (Table I).

The data presented further show that as depth increases there is sudden drop in the organic matter content. Compared to the top layer the other two layers contain practically very little organic matter.

The chloride content of the water-soluble portion of the mud samples follow a definite pattern, being very high up to $3 \%$ in October, when the mud is dry and falling considerably during the period of inundation of the area, the chloride content at this period being $0.7 \%$. This low chloride is thereafter maintained even when the lagoons get a regular supply of sea-water. But the value increases again when the lagoons are cut off from the sea due to deposition of sodium chloride crystals over the surface soil. This may partly be responsible for the limited bacterial activity of the muds during the dry season. Even in the bottom layers of the muds there is some variation in the chloride content but the actual percentage is seen to be comparatively small especially in Station I. The same cycle of changes could be observed in regard to the water-soluble sulphate and calcium content of the samples. The total nitrogen content of the samples remains steady although the collections taken in February and April give slightly lower values. But the nitrogen content is restored as the lagoons dry up. In this connection it may be interesting to compare the corresponding value obtained for a sample of mud from the fish ponds of Indonesia.* The sample analysed is as follows:-

* This sample was taken near Djakarta, Indonesia, by Dr. N. K. Panikkar in 1954. 


\begin{tabular}{lllll} 
& & & \multicolumn{2}{c}{$\%$} \\
Combined water & $\ldots$ & $\ldots$ & $\ldots$ & $12 \cdot 6$ \\
Loss on ignition & $\ldots$ & $\ldots$ & $\ldots$ & $27 \cdot 14$ \\
Silt & $\ldots$ & $\ldots$ & $\ldots$ & $50 \cdot 0$ \\
Total calcium & $\ldots$ & $\ldots$ & $\ldots$ & $0 \cdot 184$ \\
Total sodium & $\ldots$ & $\ldots$ & $\ldots$ & $0 \cdot 18$ \\
Total chloride & $\ldots$ & $\ldots$ & $\ldots$ & $\mathrm{Nil}$ \\
Nitrogen & $\ldots$ & $\ldots$ & $\ldots$ & $0 \cdot 325$ \\
Total $\mathrm{Fe}_{2} \mathrm{O}_{3}, \mathrm{Al}_{2} \mathrm{O}_{3}$, & etc. & $\ldots$ & $\ldots$ & $28 \cdot 4$
\end{tabular}

It is clear from the above results that the Palk Bay Lagoon muds are very poor in all the constituents, particularly silt, organic matter and nitrogen contents. The Indonesian mud sample is completely devoid of chloride as against the Palk Bay Lagoon muds.

The amount of inorganic nitrogen is negligibly small at both stations throughout the period and this is completely utilized during growth of planktonic organisms in the water. The decrease in the total organic nitrogen during this period is evidence of its decomposition and utilization by the growing organisms.

Only three sets of samples were analysed for their phosphorus content. The values show that the total phosphorus content of the surface samples decreases when the lagoons are inundated but the original level is restored when the area becomes dry again. In contrast to this the interstitial phosphate does not seem to alter much. The lowering of the total phosphorus is always followed by a decrease in the silt content during this period. This indicates that a portion of the phosphorus which is mostly in the organic form is carried to the supernatant layers of water along with the silt when the lagoons get inundated.

Both the nitrogen and phosphorus decrease with depth as observed by Moore (1930). But in this connection it may be said that the quantities of these elements present in the lagoon muds are extremely small compared to the values recorded for marine muds by the above author and for estuarine muds by Rochford (1951). The other soluble constituents of the soil like $\mathrm{Ca}$, and $\mathrm{SO}_{4}$ follow the same cycle of changes as with chloride while the manganese and water-soluble iron contents do not show any appreciable change. 


\section{SUMMARY AND CONCLUSION}

Data have been collected on the $\mathrm{pH}$, organic matter, total nitrogen, total and interstitial phosphorus and some of the water-soluble constituents of bottom muds collected from two stations in the Palk Bay Lagoons. The data indicate that the muds are very poor in essential nutrients and undergo drastic changes in their composition as a result of the extreme ecological conditions to which the lagoons are subjected. It is also noticed that the top layers of the mud are richer than the bottom soil and this is highly significant from the point of view of using the lagoons for fish cultivation.

\section{ACKNOWLEDGEMENT}

I am grateful to Dr. N. K. Panikkar, Chief Research Officer, Central Marine Fisheries Research Station, Mandapam Camp, for his continued interest in the work.

\section{REFERENCES}

Krishna Pillai, V.

Mortimer, G. H.

Moore, H. B.

Rochford, D. J.
.. Symposium on Marine and Fresh-Water Plankton of the IndoPacific, 1954, 78-81.

.. Proc. nat. Inst. Sci., 1955, 21, 90-102.

.. J. Ecol., 1941, 29, 280-329.

.. Ibid., 1942, 30, 147-201.

.. J. Mar. Biol. Assn., U.K., 1930, 16, 595-607.

. . Austr. J. Mar. Fresh-Water Res., 1951, 2, 1-116.

983-56. Printed at The Bangalore Press, Bangalore City, by C. Vasudeva Rao, Superintendent and Published by The Indian Academy of Sciences, Bangalore. 